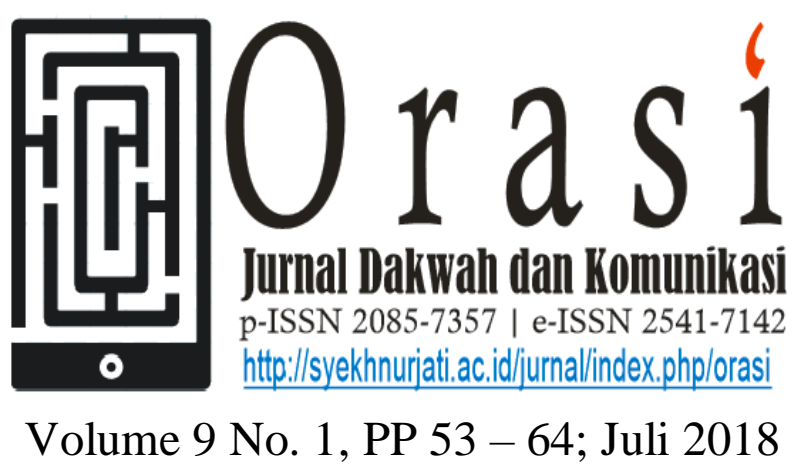

\title{
MANAJEMEN KOMUNIKASI PADA KERJA REDAKSI DALAM MENENTUKAN FOTO TUNGGAL SEBAGAI BENTUK PENYAJIAN BERITA DI MEDIA CETAK HARIAN UMUM KABAR CIREBON
}

\author{
Syahroni' ${ }^{1}$, Babay Barmawi $\mathbf{i}^{(*)}$ \\ Mahasiswa Jurusan Komunikasi dan Penyiaran Islam ${ }^{1}$ \\ Dosen Jurusan Komunikasi dan Penyiaran Islam ${ }^{2}$ \\ Fakultas Ushuluddin Adab dan Dakwah IAIN Syekh Nurjati Cirebon \\ syahroni.kpi@syekhnurjati.ac.id ${ }^{1}$, babay.barmawi@syekhnurjati.ac.id $^{(*)}$
}

\begin{abstract}
ABSTRAK
Foto jurnalistik merupakan sebuah hasil kerja yang dilakukan oleh seorang wartawan atau pewarta foto. Penelitian ini bertujuan untuk mengetahui manajemen komunikasi pada kerja redaksi dalam menentukan foto tunggal, mengetahui mekanisme kerja redaksi dalam menghasilkan foto tunggal, mengetahui kriteria foto yang dapat dijadikan foto tunggal di Harian Umum Kabar Cirebon. Metodologi penelitian yang digunakan adalah jenis penelitian kualitatif dengan pendekatan deskriptif. Sumber data yang pertama yaitu sumber data primer, yakni data utama yang diperoleh melalui proses wawancara mendalam dengan jajaran bidang redaksi. Kedua yaitu data sekunder yang berasal dari buku-buku, tulisan ilmiah, browsing internet dan lain sebagainya. Teknik pengumpulan data yang digunakan diantara observasi, wawancara mendalam, dokumentasi. Teknik analisis data menggunakan teknik analisis data yang biasa digunakan dalam studi deskriptif. Informan terdiri dari Pemimpin Redaksi, Redaktur Foto, dan Wartawan. Berdasarkan hasil penelitian dapat diketahui: (1) Kerja redaksi dalam menentukan foto tunggal berawal dari arahan pemimpin redaksi kepada jajarannya dengan melakukan komunikasi formal, komunikasi non-formal, komunikasi prosedur, komunikasi teknis. Selain itu pemimpin redaksi memiliki tugas untuk melakukan komunikasi eksternal dengan pihak luar. (2) Selain berdasarkan rapat proyeksi dan tugas khusus, para wartawan bisa berinisiatif untuk mengangkat tema berita ketika melakukan tugas liputan di lapangan tanpa menunggu arahan dari atasan. (3) Kriteria foto tunggal sendiri di antaranya harus memiliki fokus teknis dan fokus pesan dan mengandung unsur $5 W+1 \mathrm{H}$. Selain itu, foto tunggal harus disertai keterangan atau caption.
\end{abstract}

Kata Kunci: Manajemen, Redaksi, Fotografi, Jurnalistik, Foto Tunggal 


\section{PENDAHULUAN}

Foto jurnalistik dapat dikatakan sebuah metode berkomunikasi melalui sebuah foto atau gambar, sehingga foto jurnalistik bisa menjadi sebuah berita atau informasi yang dibutuhkan oleh masyarakat, baik lokal, nasional maupun pada tingkat internasional. foto jurnalistik merupakan sebuah hasil kerja yang dilakukan oleh seorang wartawan atau pewarta foto. Perwarta foto sendiri merupakan awak redaksi yang bertanggung jawab dalam mencari dan mendapatkan sebuah foto untuk mendukung sebuah berita yang akan disajikan dalam surat kabar.

Perkembangan fotografi menjadi begitu terasa oleh para pembaca media massa. Terlebih di antara pengelola media, sepertinya telah memperlakukan keberadaan sebuah foto atau gambar yang terlihat sederhana menjadi suatu media penyampai berita yang handal. Satu foto sudah dapat ditafsirkan dengan ribuan kata, cerita dan makna. Foto secara langsung telah dapat merespon yang melihatnya tanpa melalui penalaran yang harus dicerna oleh otak, kemudian memaknai apa yang disampaikannya sebagai sesuatu yang sangat diperhitungkan di dalam sebuah media (Sugiarto, 2014: 5).

Kita sering mendengar istilah, satu foto mengandung seribu bahasa. Istilah tersebut mengisyaratkan betapa pentingnya kehadiran foto dalam media apapun. Begitu pula halnya dalam dunia jurnalistik, kehadiran foto menjadi unsur yang sangat penting. Kehadiran foto jurnalistik memberi pesan yang kuat dibenak pem2baca. Seringkali emosi pembaca menjadi hanyut dan terbuai akibat tampilan foto yang disajikan dalam sebuah media massa, salah satunya surat kabar (Yunus, 2010: 90).

Foto di media cetak lebih bertahan lama daripada adegan bergerak televisi di benak orang yang melihatnya. Adegan manusia mendarat di bulan misalnya, orang akan lebih ingat gambar diamnya daripada adegan rekaman videonya.

Foto tunggal sendiri berarti foto jurnalistik yang dibuat secara tunggal (single), apakah itu tentang kehidupan manusia sehari-hari (human interest) atau yang bersifat berita news dan olahraga sekalipun. Sebagai syarat kelengkapan membuat foto jurnalistik bagi sebuah publikasi media cetak, akan menjadi lebih baik jika disertai beberapa keterangan yang berhubungan dengan kejadian untuk membantu pemerhati foto menangkap pesan yang disampaikan (Sugiarto, 2014: 80)

Untuk melengkapi informasi suatu peristiwa yang terdapat pada sebuah foto dalam media cetak diperlukan caption atau keterangan sebagai teks yang menjelaskan 
berita yang terkandung dalam foto tersebut agar dapat dipahami oleh para pembaca.

Caption atau keterangan foto, yang dalam dunia jurnalistik di mana penulisannya mengacu pada unsur-unsur kelengkapan sebuah berita yaitu mengandung $5 \mathrm{~W}+1 \mathrm{H}$ atau apa, siapa, kapan, di mana dan mengapa, dapat menjadikan sebuah foto yang menuturkan peristiwanya secara jelas, dapat menjadi lebih jelas. Dan karena itu, tidak akan berarti apa-apa bila sebuah karya foto dalam dunia jurnalistik tanpa keterangan foto yang menyertainya (Sugiarto, 2014: 77).

Foto jurnalistik yang optimal dipastikan dapat ikut menjual media yang bersangkutan. Apalagi dalam media cetak, kualitas foto yang baik sama pentingnya dengan berita yang objekif. Media cetak harus dipahami sebagai produk yang menggabungkan dua media komunikasi verbal dan visual. Foto jurnalistik memiliki peran penting dalam menentukan kualitas media cetak, sekalipun secara proporsi relatif lebih sedikit dari berita yang disajikan (Yunus, 2012:95).

Untuk mengoptimalkan hasil foto jurnalistik, wartawan foto harus terinspirasi untuk selalu memberikan sesuatu yang baru kepada pembaca. Sesuatu yang baru dapat diimplementasikan dalam bentuk gambar foto yang unik dan tidak lazim dalam pengambilan gambar foto, dalam hal ini kreativitas juga menjadi elemen yang diperlukan dalam kegiatan foto jurnalistik.Kreativitas wartawan foto pun dapat diimplementasikan dalam pembuatan caption atau keterangan foto (Yunus, 2012: 96).

Untuk dapat menghasilkan produk berita yang sesuai dengan kebijakan perusahaan, baik berbentuk tulisan maupun foto dibutuhkan manajemen komunnikasi yang baik di bagian redaksi. Arahan dari atasan dalam hal ini pemimpin redaksi di sebuah perusahaan surat kabar sangat dibutuhkan agar setiap yang dilakukan oleh para awak media dalam kegiatan liputan dapat meraih hasil optimal dan tidak melanggar rambu-rambu yang harus ditaati oleh setiap insan pers indonesia, tak terkecuali Harian Umum Kabar Cirebon.

Sebagai salah satu media massa yang mempunyai usia cukup tua dibanding dengan media massa yang lain, surat kabar mempunyai fase perkembangan yang stabil. Perubahan yang terjadi hanya dari segi kualitas pelaporan, pola pelaporan dan tampilannya. Media cetak termasuk jenis media massa yang paling populer. Media cetak merupakan media komunikasi yang bersifat tertulis atau tercetak. Jenis media cetak yang beredar di masyarakat sangat beragam, diantaranya ialah surat kabar, majalah dan tabloid (Suryawati, 2014: 40).

Media merupakan lokasi atau forum yang berperan untuk menampilkan 
peristiwa-peristiwa kehidupan masyarakat, baik yang bersifat nasional ataupun internasional. Dia menjadi sumber pedoman, bukan saja bagi individu untuk memperoleh gambaran dan citra realitas sosial, tetapi juga bagi masyarakat atau kelompok secara kolektif yang dibaurkan dengan berita dan hiburan (McQuail, 1994:03).

Beberapa foto tunggal yang terdapat pada Harian Umum Kabar Cirebon adalah foto seorang korban pencurian dan kekerasan. Pada foto tersebut terlihat korban yang sedang dipapah kerabatnya ketika hendak melaporkan kejadian tersebut ke Mapolres Cirebon Kota. Selain itu, terdapat pula foto STAF Kesejahteraan Rakyat Kelurahan Kuningan, sedang melakukan pendistribusian Beras Sejahtera (Rastra) dari program Kementrian Sosial (Kemensos) kepada warganya yang hendak menukarkan kupon rastra (Kabar Cirebon, 26 September 2017).

Harian Umum Kabar Cirebon adalah salah satu harian umum yang berkembang di tengah masyarakat sampai saat ini. Sebagai koran lokal yang edisinya terbit setiap hari dengan menyajikan berbagai informasi berita. Harian Umum Kabar Cirebon hadir di tengah-tengah pembaca yang pesat, khususnya wilayah Cirebon, Indramayu, Majalengka dan Kuningan (Ciayumajakuning). Kabar Cirebon merupakan salah satu surat kabar lokal yang ada di Indonesia khususnya di Cirebon, jawa barat. Sesuai namanya, surat kabar ini berisi tentang berita atau informasi seputar daerah Cirebon dan sekitarnya. Surat kabar ini didirikan pada tahun 1999 yang semula bernama Mitra Dialog. Kabar Cirebon merupakan anak dari surat kabar Pikiran Rakyat yang berpusat di bandung (Dokumen Kabar 2014).

\section{METODOLOGI PENELITIAN}

Dalam penelitian ini, peneliti menggunakan jenis penelitian kualitatif. Penelitian kualitatif pada dasarnya adalah penelitian yang bersifat eksploratif. Penelitian ini berusaha menerangkan sesuatu yang terjadi, di mana permasalahan sosial digali secara mendalam untuk mengetahui suatu kejadian atau proses yang sedang berlangsung di suatu daerah atau tempat (Bungin, 2012:69).

Metode yang digunakan dalam penelitian ini adalah metode deskriptif dengan tujuan memaparkan situasi atau peristiwa. Penelitian ini tidak mencari atau menjelaskan hubungan, tidak menguji hipotesis atau membuat prediksi (Rakhmat, 2012: 24).

Penelitian deskriptif kualitatif dimana data kumpulkan dan dinyatakan 
dalam bentuk kata-kata dan gambar yang disusun pada sebuah kalimat. Misalnya kalimat hasil wawancara. Penelitian kualitatif bertolak dari filsafat konstrukivisme yang berasumsi bahwa kenyataan itu berdimensi jamak, interaktif, dan suatu pertukaran pengamalan sosial yang diinterpretasikan oleh individuindividu. Penelitian kualitatif ditujukan untuk memahami fenomena-fenomena sosial dari sudut perspektif partisipan. Partisipan sendiri adalah orang-orang yang terlibat dalam proses wawancara, memberikan data, pendapat, dan pemikiran (Sukmadinata, 2006: 94).

Dalam proses penelitian ini peneliti menggunakan teknik pengumpulan data yaitu observasi, wawancara mendalam, dokumentasi. Dalam wawancara peneliti dapat melakuan face to face (wawancara berhadap-hadapan) dengan partisipan, mewawancarai mereka dengan telepon atau terlibat dalam focus group interview (interview dalam kelompok tertentu. Wawancra-wawancara seperti ini tentu saja memerlukan pertanyaan-pertanyaan yang secara umum tidak terstruktur dan bersifat terbuka yang dirancang untuk memunculkan pandangan dan opini dari para partisipan (Creswell, 2015: 267).. Selama proses penelitian, peneliti juga bisa mengumpulkan dokumen-dokumen yang bisa berupa dokumen publik (seperti koran, makalah, laporan kantor) ataupun dokumen privat (seperti buku harian, diary, surat, email), materi audio dan visual (seperti foto, objek-objek seni, vidoetape, atau segala jenis suara/bunyi) (Creswell, 2015: 270).

\section{HASIL DAN PEMBAHASAN}

Komunikasi formal dalam hal ini dapat dilakukan dengan mengadakan rapat redaksi yang dilaksanakan setiap hari, terutama dalam penyusunan proyeksi liputan maupun dalam penentuan berita yang dilakukan pada sore hari. Selain rapat redaksi, komunikasi formal dapat terjadi pada saat evaluasi hasil kerja.

Proses pembuatan berita yang sifatnya tertulis maupun gambar biasa dimuali dari rapat redaksi yang juga merupakan jantung operasional media pemberitaan. Rapat redaksi merupakan kegiatan rutin yang penting bagi pengembangan dan peningkatan kualitas berita yang dihasilkan.

Evaluasi kerja adalah proses yang digunakan pimpinan untuk menentukan apakah seorang karyawan dalam hal ini jajaran redaksi termasuk wartawan melakukan pekerjaan sesuai dengan tugas dan tanggungjawabnya.

Dalam proses evaluasi kerja redaksi di Harian Umum Kabar Cirebon memiliki tugasnya masing-masing, di antaranya: 
1. Pemimpin redaksi mengevaluasi pemberitaan secara umum.

2. Redaktur pelaksana teknis pemberitaan seluruh halaman.

3. Redaktur bagian mengevaluasi halaman yang menjadi tanggungjawabnya.

Evaluasi kerja dilakukan secara terjadwal, mulai dari harian, bulanan, dan tahunan. Pemimpin redaksi Harian Umum Kabar Cirebon Dudung Abdul Hakim memiliki persepsi bahwa evaluasi hasil kerja sangat perlu dilakukan, karna tanpa evaluasi jajaran redaksi berpotensi melakukan kesalahan yang sama berulangulang, atau bahkan lebih buruk

Pemimpin redaksi di Harian Umum Kabar Cirebon sendiri memiliki peran dan tanggungjawab yang sangat besar di bidang keredaksian. Tugas utamanya secara umum adalah:

1. Membantu Pemimpin Umum merumuskan program perusahaan, yang berkaitan dengan bidang redaksional.

2. Membantu Pemimpin Umum merumuskan rancangan peraturan umum maupun peraturan perusahaan, yang berkaitan dengan penyelenggaraan bidang redaksional.

3. Mengkaji isi redaksional surat kabar Harian Umum Kabar Cirebon.

4. Melakukan kaji banding antara isi redaksional Surat Kabar Harian Umum
Kabar Cirebon dengan perusahaan surat kabar lain.

5. Berdasarkan hasil kaji banding kemudian melakukan perbaikanperbaikan yang diperlukan.

6. Menjalin dan membina keterpaduan, keselarasan, dan koordinasi dengan bagian-bagian lain.

7. Membina dan menjalin hubungan kerja sama dengan pihak di luar perusahaan.

8. Memberikan laporan dan pendapat, usul atau saran kepada Pemimpin Umum.

9. Dalam menjalankan tugasnya pemimpin redaksi dibantu oleh beberapa tenaga, di antaranya redaktur pelaksana dan para redaktur halaman. Jumlah anggotanya tergantung dari banyaknya halaman dan bidang liputan yang disajikan.

Adapun tugas Redaktur Pelaksana Harian Umum Kabar Cirebon di antaranya:

a. Menjabarkan secara teknis operasional pelaksanaan kebijakan redaksional yang sudah ditetapkan oleh Pemimpin Redaksi.

b. Memberikan pengarahan teknis kepada Redaktur.

c. Mengkoordinasikan dan membina para redaktur.

d. Melakukan general final cheking atas isi redaksional yang akan disiarkan, dan jika dianggap perlu dapat melakukan perubahan-perubahan berita tulisan dan foto. 
e. Meneliti isi redaksional koran setelah terbit.

f. Memperlajari isi surat kabar lain serta mengkaji dan bandingkan dengan surat kabar Harian Umum Kabar Cirebon.

g. Membantu Pemimpin Redaksi mengawasi jajaran redaksi.

h. Mengajukan saran, usul, pertimbangan kepada Pemimpin Redaksi.

i. Menjalin keterpaduan keselarasan, dan koordinasi dengan bagian-bagian lain.

j. Untuk menindaklanjuti arahan yang disampaikan oleh pemimpin redaksi kepada jajarannya, selanjutnya seorang redaktur yang menangani berita tulis dan foto memberi tugas kepada para wartawan untuk melakukan liputan ke lapangan.

Pada Harian Umum Kabar Cirebon seorang wartawan bisa langsung berkoordinasi dengan redaktur ataupun sebaliknya ketika menemukan secara spontan sebuah isu untuk dijadikan sebuah berita yang sebelumnya tidak dibahas dalam rapat proyeksi. Hal tersebut bisa dilakukan melalui sambungan telepon. Seperti yang dijelaskan oleh wartawan foto Iwan.

Dalam menghasilkan foto tunggal yang sesuai dibutuhkan kebijakan tertentu yang diterapkan oleh pihak redaksi pada sebuah media cetak atau surat kabar tersebut. Hal ini pun telah dilakukan oleh Harian Umum
Kabar Cirebon dalam menghasilkan foto tunggal yang sesuai dengan ketentuan untuk memenuhi kebutuhan berita atau gambar yang di antaranya:

a. Foto diambil beberapa kali, sebagai alternatif pilihan foto terbaik.

b. Foto diambil dalam berbagai variasi posisi, misalnya saat bekerja, close up, saat interview.

c. Posisi kamera harus disesuaikan dengan objek foto, baik horizontal atau vertikal.

d. Sertakan teks foto (caption)

e. Cantumkan nama fotografer pada gambar.

Komunikasi ekternal di Harian Umum kabar Cirebon terjadi ketika seorang pemimpin redaksi menjalankan yang sudah menjadi tugasnya yaitu membina dan menjalin hubungan kerja sama dengan pihak di luar perusahaan, yang bertujuan agar dapat terjadi sinergi dan terjalin tali silaturahmi juga dapat saling menguntungkan.

Foto tunggal sebagai salah satu bentuk penyajian berita, setidaknya harus mempunyai unsur-unsur yang sama seperti halnya dengan berita dalam bentuk tulisan, yaitu memuat unsur apa (what), siapa (who), di mana (where), kapan (when) dan mengapa (why). Perbedanya dalam bentuk visual, foto berita mempunyai kelebihan 
dalam menyampaikan unsur (how) nya, yaitu bagaimana kejadia itu berlangsung.

Foto tunggal bisa dikatakan layak dan dapat dibutuhkan sewaktu-waktu dengan syarat kualitas gambar harus jelas dan tidak buram, serta memiliki mutu yang bagus untuk dijadikan sebuah berita.

Dalam fotografi jurnalistik, foto dapat dikatakan berhasil atau memenuhi kriteria dapat dinilai secara sederhana yaitu fokus dan tidaknya foto. Namun demikian fokus itu sendiri dapat berarti dua pengertian yang berbeda, yaitu:

a. Fokus teknis.

Fokus teknis adalah fokus yang menjelaskan secara gambar akan tajamnya subjek sehingga tidak tampak buram.

b. Fokus cerita atau pesan.

Fokus di sini maksudnya adalah fokus yang dapat menerangkan secara jelas pesan yang terkandung dalam foto.

Dalam foto jurnalistik, foto bagus bisa tidak berarti apa-apa tanpa caption. Karena keberadaan caption sama penting dengan gambar itu sendiri. Pembaca tidak perlu menerka-nerka pesan dalam foto. Dalam upaya menampilkan sisi paling menarik dari sebuah foto hendaknya seorang wartawan mampu menentukan caption yang sesuai sebagai penegasan pada gambar agar dapat mudah dipahami oleh para pembaca terkait isu yang sedang diangkat. Caption kadang mampu menggiring mata untuk kembali melihat foto. Seperti yang ditegaskan oleh pemimpin redaksi Dudung Abdul Hakim:

\section{"Dalam menentukan caption, yang terpenting adalah kemampuannya menegaskan sisi paling menarik dari sebuah foto. Meskipun pembaca memahami itu dengan hanya melihat fotonya, mereka tetap membutuhkan penegasan, di sini unsur $5 \mathrm{~W}+1 \mathrm{H}$ sebisa mungkin terpenuhi”}

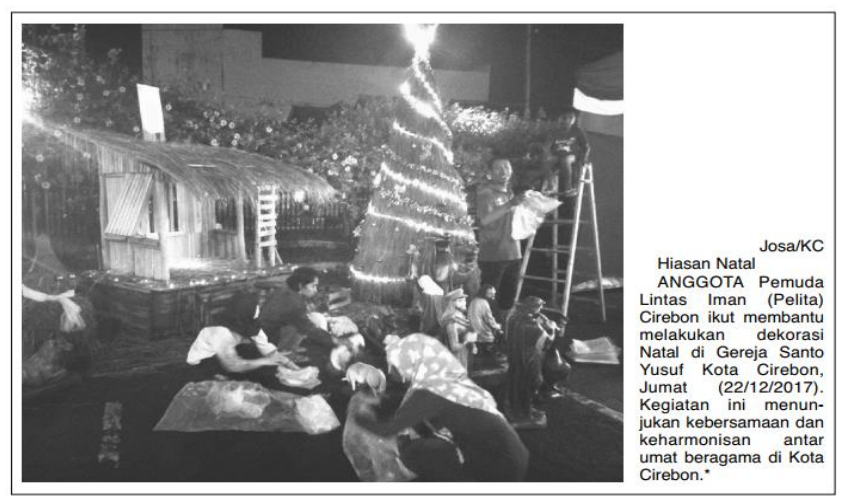

Gambar 1. Caption Samping Foto

Caption sendiri harus dibuat dengan menggunakan bahasa sederhana agar mudah dicerna dan dipahami oleh masyarakat dalam sekali melihat foto. Seperti yang dijelaskan oleh seorang wartawan foto di Harian Umum Kabar Cirebon Iwan yang mengatakan:

"Caption itu bahasanya harus sederhana agar mudah dicerrna dan dipahami oleh pembaca dalam sekali melihat gambar di koran, dengan ketentuan memenuhi unsur $5 \mathrm{~W}+1 \mathrm{H}$. Walapun hanya tiga unsur itu sudah mencukupi. Jadi tidak perlu panjang karena ini bukan berita yang sifatnya tertulis". 
Untuk penempatannya sendiri caption harus diletakan di dekat gambar yang dideskripsikannya, entah itu di sebelah atau di bawahnya tergantung posisi foto pada saat mengisi suatu halaman yang ditentukan oleh bagian perwajahan. Seperti yang disampaikan oleh pemimpin redaksi Dudung Abdul Hakim yang mengatakan:

"Penempatan caption sendiri biasanya di bawah foto, tapi juga tidak menutup kemungkinan diletakan di samping kiri. Itu disesuaikan dengan perwajahan halaman"

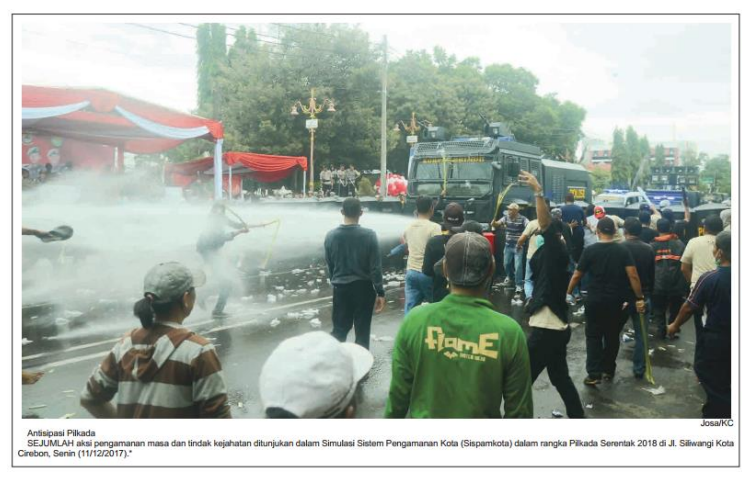

Gambar 2. Caption di bawah Foto

Seperti pada contoh Gambar 2 di atas. Berita foto yang berjudul Antisipasi Pilkada, dengan caption sejumlah aksi pengamanan massa dan tindak kejahatan ditunjukan dalam Simulasi Sistem Pengamanan Kota (Sispamkota) dalam rangka Pilkada Serentak 2018 di Jl. Siliwangi Kota Cirebon, Senin (11/12/2017). Pada gambar tersebut, terlihat posisi caption dekat dengan foto yang dideskripsikannya, tepatnya di bawah foto.

Caption merupakan teks atau keterangan yang menyertai foto jurnalistik.
Caption membantu mengarahkan perspektif sebuah foto dan menjelaskan secara detail informasi yang tidak ada pada gambar, agar tidak membingungkan para pembaca yang melihat, karena tidak semua unsur dalam foto mampu menjelaskan isi berita, seperti di mana lokasi sebuah gambar diambil (where), kapan waktu kejadiannya (when) dan siapa yang ada di dalam foto tesebut (who). Namun caption sendiri seharusnya tidak mengulang informasi yang sudah tertampung pada gambar. Seperti yang dijelaskan oleh redaktur foto Andi Arifin bahwa:

"Caption sendiri bukan hanya sekedar mendeskripsikan sebuah gambar, tapi lebih memberi keterangan atau info yang belum tersampaikan oleh foto"

Langkah yang dilakukan oleh jajaran redaksi untuk menentukan caption sendiri yaitu, wartawan tulis atau wartawan foto diharuskan membuat keterangan untuk menyertai foto yang telah dipilih sebelum menyerahkan hasil jepretannya ke bagian redaksi. Seperti yang dikatakan oleh redaktur foto Andi Arifin:

"Ketika dalam proses penyerahan gambar hasil liputan, baik wartawan tulis atau wartawan foto diwajibkan melengkapi gambar yang dipilih dengan caption"

Secara teknis dalam proses menghasilkan dan menentukan caption untuk mendampingi sebuah foto mengenai suatu kejadian atau peristiwa hal yang dapat dilakukan oleh seorang pewarta foto di 
antaranya melakukan wawancara kepada narasumber di tempat kejadian, kemudian menyertakannya pada sebuah foto sebanyak kurang lebih dua kalimat, yang bisa mencakup waktu (When) atau tempat kejadian (Where) atau unsur lain tergantung pesan apa yang ingin disampaikan, kemudian pada kalimat kedua menyampaikan data terkait isu yang sedang terjadi dan akan diangkat. Seperti yang dijelaskan oleh wartawan foto Josa:

"Setelah memotret, kita lakukan wawancara kepada narasumber untuk mendapatkan data yang nantinya bisa dijadikan keterangan pada foto. Caption sendiri bisasanya terdiri dua kalimat. Kalimat pertama bisa menunjukan tempat atau waktu kejadian, kalimat kedua isu yang akan kita angkat"

\section{SIMPULAN DAN SARAN}

\section{Simpulan}

Berdasarkan hasil penelitian yang diperoleh mengenai manajemen komunikasi pada kerja redaksi dalam menentukan foto tunggal sebagai bentuk penyajian berita di media cetak Harian Umum Kabar Cirebon, maka dapat ditarik kesimpulan sebagai berikut:

a. Untuk dapat mencapai target yang diinginkan terkait isi berita yang akan dipublikasikan kepada pembaca diperlukan beberapa manajemen komunikasi untuk mengkoordinasikan jajaran redaksi dalam melakukan tugasnya. Beberapa bentuk manajemen komunikasi yang dapat diterpakan di antaranya, komunikasi formal, komunikasi non-formal, komunikasi prosedural, komunikasi teknis, dan komunikasi eksternal.

1. Mekanisme kerja redaksi Harian Umum Kabar Cirebon dalam menentukan foto tunggal berawal dari arahan pemimpin redaksi kepada jajarannya yang dilakukan dengan cara formal dan nonformal yang kemudian diarahkan kepada wartawan. Kebijakan yang diterapkan redaksi dalam menghasilkan dan menentukan foto tunggal di antaranya: (a) Foto diambil beberapa kali sebagai alternatif pilihan foto terbaik, (b) Foto diambil dari berbagai posisi, (c) Posisi kamera disesuaikan dengan objek yang akan difoto, (d) Sertakan caption/teks foto, (e) Cantumkan nama fotografer pada gambar.

2. Kriteria foto yang dapat dijadikan foto tunggal di Harian Umum Kabar Cirebon di antaranya gambar yang optimal dan merupakan foto terbaik dari beberapa foto yang didapat. Foto jurnalistik dapat dikatakan berhasil dapat dinilai dengan sederhana yaitu fokus dan tidaknya. Fokus yang dimaksud memiliki dua arti, yaitu fokus teknis dan fokus pesan. Foto tunggal harus mampu menampilkan sisi 
unik dan menarik juga mudah dipahami oleh pembaca dan mengandung unsur $5 \mathrm{~W}+1 \mathrm{H}$. Selain itu pada foto harus disertakan caption/teks foto untuk mengarahkan dan menjelaskan secara detail informasi yang terdapat pada foto, dimana kalimat pertama menjelaskan gambar dan kalimat kedua menjelaskan data.

Sebelum melakukan penugasan kepada wartawan dalam kegiatan liputan berita tulis maupun foto, jajaran redaksi harus sudah menentukan tema berita yang akan di angkat. Adapun beberapa kriteria tema yang diterapkan menurut Pemimpin Redaksi Dudung Abdul Hakim di antaranya:

1. Hangat.

Hangat di sini artinya isu sedang menjadi topik utama perbincangan di ruang publik.

2. Dekat dengan publik.

Dekat di sini artinya memiliki hubungan yang erat dengan pembaca dan berdampak pada kehidupan mereka sehari-hari.

\section{Saran}

Penelitian ini diharapkan dapat bermanfaat dan menambah pengetahuan untuk para praktisi di media cetak dalam upaya menentukan foto tunggal sebagai bentuk penyajian berita.

\section{DAFTAR PUSTAKA}

Alwi, Audi, M. 2008. Foto Jurnalistik Metode Memotret dan Mengirim ke Media Massa. Jakarta: PT. Bumi Aksara

Ardianto, Elvirano, Lukiati Komala dan Siti Karlinah. 2012. Komunikasi Massa. Bandung: Simbiosa Rekatama Media.

Baran, Stanley J. 2012. Pengantar Komunikasi Massa. Jakarta: Erlangga.

Burhan, Bungin. 2012. Penelitian kualitatif. Jakarta: Pranada Media Group.

Creeswell, W, John. 2015. RESEARCH DESIGN. Yogyakarta: Pustaka Pelajar.

Emzir. 2012. Metodologi Penelitian Kualitatif: Analisis Data. Jakarta: PT. Raja Grafindo Persada.

File Kabar Cirebon 2014

Gunawan, Imam. 2015. Metode Penelitian Kualitatif: Teori dan Praktek. Jakarta: Bumi Aksara

HM, Zaenuddin. 2011. The Journalist: Bacaan Wajib Wartawan Redaktur, Editor, dan Mahasiswa Jurnalistik. Bandung: Simbiosa Rekatama Media.

Kusumaningrat, Hikmat dan Purnama Kusumaningrat. 2012. Jurnalistik Teori dan Praktik. Bandung: Remaja Rosdakarya.

Liliweri, Alo. Komunikasi Serba Ada Serba Makna. Jakarta: Kencana Predana Media Group.

McQuail, Denis. 1994. Teori Komunikasi Suatu Pengantar. Jakarta: Erlangga. 
Mondry. 2008. Pemahaman Teori dan Praktik Jurnalistik. Bogor: Ghalia Indonesia.

Muhtadi, Saeful, Asep. 1999. Jurnalistik (Pendekatan Teori dan Praktik). Ciputat: PT. LOGOS Wacana Ilmu.

Rolnicki, Tom E, C. Dow Tate, Sherri A. Taylor. 2008. Pengantar Dasar Jurnalisme. Jakarta: Kencana Predana Media Group.

Santana, Septiawan, K. 2005. Jurnalisme Kontemporer. Jakarta: Yayasan Obor Indonesia.

Sukmadinata. 2006. Metode Penelitian Pendidikan. Bandung: remaja Rosdakarya

Sumadiria, Haris. 2014. Jurnalistik Indonesia. Bandung: Simbiosa Rekatama Media.

2006. Bahasa Jurnalistik. Bandung: Remaja Rosdakarya.

Suryawati, Indah. 2011. Jurnalistik Suatu Pengantar. Bogor: Ghalia Indonesia.

Sugiarto, Atok. 2014. Jurnalisme Pejalan Kaki. Jakarta: PT. Elex Media Komputindo.

Sugiyono. 2011. Metode Kuantitatif Kualitatif dan $R$ \& $D$. Bandung: Alfabeta.
Suhandang, Kustadi. 2004. Pengantar Jurnalistik, Seputar Organisasi, Produk, dan Kode Etik. Bandung: Nuansa.

Tebba, Surdirman. 2005. Jurnalistik Baru. Jakarta: Kalam Indonesia.

Wijaya, Taufan. 2014. Foto Jurnalistik. Jakarta: PT. Gramedia Pustaka Utama.

Yunus, Syarifudin. 2012. Jurnalistik Terapan. Bogor: Ghalia Indonesia.

\section{Sumber Skripsi:}

Aziz, Abdul. 2015. Foto Jurnalistik Pemakaman Walikota Cirebon pada Surat Kabar di Cirebon (Analisis Semiotik Foto Jurnalistik Pemakaman Walikota Cirebon dalam Menyampaikan Pesan Berita dan Pesan Dakwah pada Surat Kabar Radar Cirebon dan Kabar Cirebon. (Skripsi). Cirebon: Institut Agama Islam Negeri Syekh Nurjati.

Kurnaedi, Dedi. 2017. Pemahaman Wartawan Terhadap Pedoman Pemberitaan Media Siber dan Tanggapan Langsung Pada Berita Yang Dimuat di Media Online radarcirebon.com. (Skripsi). Cirebon: Institut Agama Islam Negeri Syekh Nurjati.

Rachmadani, Vita, Anggi. 2015. Mekanisme Kerja Redaksi dalam Menentukan Headline Berita. (Skripsi). Cirebon: Institut Agama Islam Negeri Syekh Nurjati. 